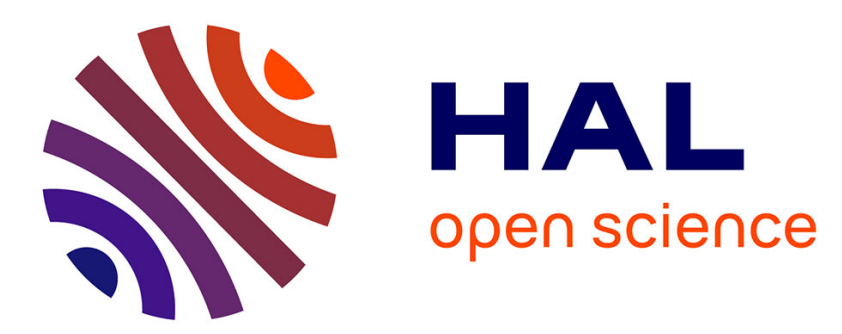

\title{
Investigation of Bulging During Impact in Composite Armour
}

\author{
H. Senf, E. Strassburger, H. Rothenhäusler
}

\section{To cite this version:}

H. Senf, E. Strassburger, H. Rothenhäusler. Investigation of Bulging During Impact in Composite Armour. Journal de Physique IV Proceedings, 1997, 07 (C3), pp.C3-301-C3-306. 10.1051/jp4:1997353 . jpa-00255510

\section{HAL Id: jpa-00255510 https://hal.science/jpa-00255510}

Submitted on 1 Jan 1997

HAL is a multi-disciplinary open access archive for the deposit and dissemination of scientific research documents, whether they are published or not. The documents may come from teaching and research institutions in France or abroad, or from public or private research centers.
L'archive ouverte pluridisciplinaire HAL, est destinée au dépôt et à la diffusion de documents scientifiques de niveau recherche, publiés ou non, émanant des établissements d'enseignement et de recherche français ou étrangers, des laboratoires publics ou privés. 


\title{
Investigation of Bulging During Impact in Composite Armour
}

\author{
H. Senf, E. Strassburger and H. Rothenhäusler \\ Fraunhofer-Institut für Kurzzeitdynamik, Ernst-Mach-Institut (EMI), Hauptstrasse 18, \\ 79576 Weil am Rhein, Germany
}

\begin{abstract}
The deformation of composite armour during ballistic impact was investigated by means of high-speed photography. The composite targets consisted of ceramic tiles, aluminium sandwich panels with honeycomb core and glassfibre-reinforced plastics. Two types of projectiles were used, $12.7 \mathrm{~mm}$ Armour Piercing projectiles with steel core and hemispherically nosed tungsten alloy penetrators. The distance-time histories of the rear sides of the GRP panels were determined.
\end{abstract}

Résumé : La détormation de blindages composites soumis à un impact balistique a été examinée à l'aide de la photographie ultra-rapide. Les blindages composites étaient constitués de plaques céramiques, des plaques sandwich en auminium avec une structure en nid d'abeille et des plaques renforcées par tibre de verTe (GRP). Deux types de projectile ont éć utilisés: des pénétrateurs en tungstène avec une pointe hémisphérique et des projectiles perforants avec un noyau d'acier. Le déplacement en fonction du temps du côté-arrière des panneaux GRP a été déterminé.

\section{INTRODUCTION}

Ceramics and fibre-reinforced composites are important components of lightweight armour systems. The function of the ceramic layer is to break or erode the projectile whereas the fibre reinforced composite has to stop the residual projectile and the fragments generated during the penetration process. Actual armour systems mostly comprise of several layers of both types of materials. In order to understand the dynamic behaviour and the ballistic efficiency of composite armour it is necessary to know the behaviour of the single components or combinations of the utilised materials under ballistic impact. Therefore, it is important to have a diagnostic technique which allows to obtain information about the deformation of composite laminates during the penetration or perforation of a projectile.

Two different methods are mostly employed for this purpose. The target deformation in one plane of view can be recorded by means of high-speed photography in a shadow-optical arrangement. A configuration which allowed the simultaneous recording of transient deformations in two perpendicular planes of view was applied by Straßburger, Senf and co-workers [1]. Recently, Kokidko et al. [2] employed a shadow moire technique combined with high-speed photography in order to measure the deformation of glass fibre reinforced plastics (GRP) at impact of $7.62 \mathrm{~mm}$ fragment simulating projectiles (FSP). The ballistic resistance of S2-glass laminates at impact of fragment simulating projectiles was determined by Bless and Hartman [3] and Vasudev and Mehlman [4].

In this study the ballistic resistance of two-layer and three-layer configurations was determined and the dynamic deformation examined by means of high-speed photography in a shadow-optical arrangement. The composite targets consisted of ceramic tiles, aluminum sandwich panels with honeycomb core and glassfibre-reinforced plastics. Two types of projectiles were used, $12.7 \mathrm{~mm}$ Armour Piercing projectiles with steel core and hemispherically nosed tungsten alloy penetrators with aspect ratio $\mathrm{L} / \mathrm{D}=3.2$. The impact velocities were varied in the range from $700 \mathrm{~m} / \mathrm{s}$ to $1300 \mathrm{~m} / \mathrm{s}$. The distance-time histories of the rear sides of the GRP panels were determined from the sequences of shadowgraphs, taken with a CranzSchardin camera. 


\section{EXPERIMENTS}

The composite targets consisted of the following materials: AD995 $\mathrm{Al}_{2} \mathrm{O}_{3}$-ceramic tiles, aluminium sandwich panels (SP) with honeycomb core and S2-glass laminates. A compilation of properties and dimensions of the specimens is given in Table 1:

Table 1 Target components

\begin{tabular}{|c|c|c|c|}
\hline & $\begin{array}{l}\text { Ceramic } \\
\text { AD995 }\end{array}$ & $\begin{array}{c}\text { Sandwich Panel } \\
\text { Aluminium AlMg3 }\end{array}$ & $\begin{array}{c}\text { GRP } \\
\text { S2-glass/polyester laminate }\end{array}$ \\
\hline Material Specifications & Density: $3.88 \mathrm{~g} / \mathrm{cm}^{3}$ & $\begin{array}{c}\text { Facesheets: } 0.6 \mathrm{~mm} \mathrm{Al} \\
\text { Honeycomb Core: } \\
6.4 \mathrm{~mm} \text { cell size }\end{array}$ & $\begin{array}{l}\text { Density: } 2 \mathrm{~g} / \mathrm{cm}^{3} \\
\text { Fibre Volume Fraction: } 60 \% \\
\text { Fibre Weight Fraction: } 80.5 \%\end{array}$ \\
\hline $\begin{array}{l}\text { Tile/Panel Thickness } \\
\text { Specimen dimensions }\end{array}$ & $\begin{array}{c}20 \mathrm{~mm}, 22.5 \mathrm{~mm} \\
150 \mathrm{~mm} \times 150 \mathrm{~mm}\end{array}$ & $\begin{array}{c}20 \mathrm{~mm}, 50 \mathrm{~mm} \\
200 \mathrm{~mm} \times 200 \mathrm{~mm}\end{array}$ & $\begin{array}{l}10 \mathrm{~mm} \text { (20 fabric layers) } \\
320 \mathrm{~mm} \times 290 \mathrm{~mm}\end{array}$ \\
\hline
\end{tabular}

In all experiments the ceramic tiles were not confined laterally. The different layers of the targets were glued together with an epoxy. The GRP panels were fixed by screws to the back of a steel frame in order to allow bulging of the GRP and to render possible the observation of the process with a Cranz-Schardin high-speed camera. Figure 1 shows a schematic view of a cross-section through the target set-up.

Two types of projectiles were used in this study, tungsten alloy cylinders with hemispherical nose (Diameter $10 \mathrm{~mm}$, Length $32 \mathrm{~mm}$, mass $44 \mathrm{~g}$ ) and $12.7 \mathrm{~mm}$ Armour Piercing projectiles with steel core (total mass $42.8 \mathrm{~g}$, core mass $25.5 \mathrm{~g}$ ).

This paper focuses on the non-perforation tests. The experimental data are listed in Tables 2 and 3, where $v_{P}$ is the impact velocity and $T_{C e t}, T_{S P}$ and $T_{G R P}$ are the thicknesses of the target layers. The maximum dynamic height of the GRP bulge is denoted $\mathrm{H}_{\mathrm{B}, \mathrm{dyn}}$ and the residual deformation is denoted $\mathrm{H}_{\mathrm{B} \text {,res. }} \mathrm{H}_{\mathrm{B} \text {,dyn }}$ is the maximum deflection that was measured during the time interval of observa-

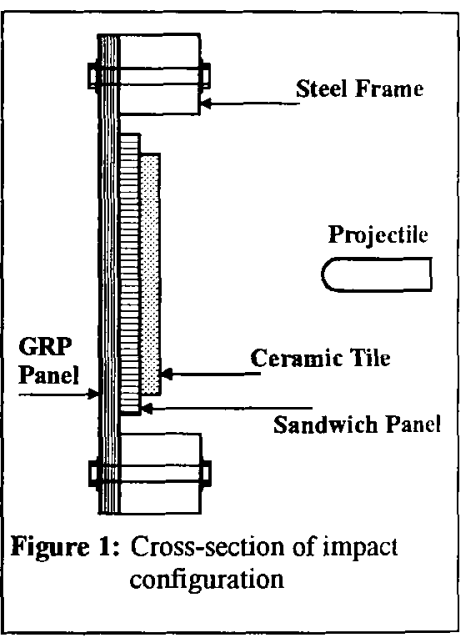
tion.

Table 2: Non-perforation tests with tungsten projectiles

\begin{tabular}{|c|c|c|c|c|c|c|}
\hline Test No. & $v_{P}[\mathrm{~m} / \mathrm{s}]$ & $\mathrm{T}_{\mathrm{Cer}}[\mathrm{mm}]$ & $\mathrm{T}_{\mathrm{SP}}[\mathrm{mm}]$ & $\mathrm{T}_{\mathrm{GRP}}[\mathrm{mm}]$ & $\mathrm{H}_{\mathrm{B}, \mathrm{dyn}}[\mathrm{mm}]$ & $\mathrm{H}_{\mathrm{B}, \mathrm{res}}[\mathrm{mm}]$ \\
\hline 11219 & 695 & 22.5 & 0 & 10 & 35 & 20 \\
\hline 11228 & 714 & 22.5 & 20 & 10 & 32 & 8 \\
\hline 11230 & 756 & 22.5 & 20 & 10 & 34 & 8.5 \\
\hline 11233 & 724 & 22.5 & 50 & 10 & 17 & 2 \\
\hline \hline 11226 & 1002 & 22.5 & 0 & 10 & 88 & 40 \\
\hline 11262 & 902 & 22.5 & 20 & 10 & $\cdots$ & $\cdots$ \\
\hline 11234 & 922 & 22.5 & 50 & 10 & 48 & 22 \\
\hline
\end{tabular}


Table 3: Non-perforation tests with steel core projectiles

\begin{tabular}{|c|c|c|c|c|c|c|}
\hline Test No. & $v_{P}[\mathrm{~m} / \mathrm{s}]$ & $\mathrm{T}_{\text {Cer }}[\mathrm{mm}]$ & $\mathrm{T}_{\mathrm{SP}}[\mathrm{mm}]$ & $\mathrm{T}_{\mathrm{GRP}}[\mathrm{mm}]$ & $\mathrm{H}_{\mathrm{B}, \mathrm{dyn}}[\mathrm{mm}]$ & $\mathrm{H}_{\mathrm{B}, \text { res }}[\mathrm{mm}]$ \\
\hline 11243 & 920 & 20 & 0 & 10 & 38 & 20 \\
\hline 11246 & 920 & 20 & 20 & 10 & 37 & 13 \\
\hline 11247 & 920 & 20 & 50 & 10 & 37 & 12 \\
\hline
\end{tabular}

\section{RESULTS AND DISCUSSION}

\subsection{Impact of tungsten projectiles}

Two series of tests were performed with the tungsten projectiles where the thickness of the sandwich panels was varied. In the first series the impact velocity was about $700 \mathrm{~m} / \mathrm{s}$ which is significantly below the ballistic limit velocity $v_{B L}$ (impact velocity where the residual velocity of the projectile is theoretically zero) for those targets. The impact velocities were chosen close to the ballistic limit velocities in the second series of tests.

In the case of the lower impact velocities no difference in the shape of the bulges could be observed. However, there were differences in the maximum bulging velocities and the dynamic and residual bulge heights. Figure 2 shows the distance-time histories of the bulges for three targets with different thicknesses of the sandwich panels. The highest bulging velocity was observed with the two-layer target. The bulging velocity decreased with increasing thickness of the sandwich panel. The bulge heights also varied in the same order (Table 2).

When the impact velocities were close to the ballistic limit velocities the maximum bulging velocities were nearly the same $(\approx 300 \mathrm{~m} / \mathrm{s})$, but the bulges exhibited different contours. The corresponding distancetime histories are plotted in Figure 3 . Figure $4 \mathrm{a}$ and $4 \mathrm{~b}$ depict a selection of shadowgraphs from the target without sandwich panel and the target with a $50 \mathrm{~mm}$ sandwich panel. In the case without sandwich panel the bulge rapidly expands over the whole GRP panel and exhibits a round contour. With the $50 \mathrm{~mm}$ sandwich panel between ceramic and GRP the bulge appears to be more localised first and exhibits a conical shape in a later stage. The dynamic bulge heights were nearly double of the residual static bulge heights.

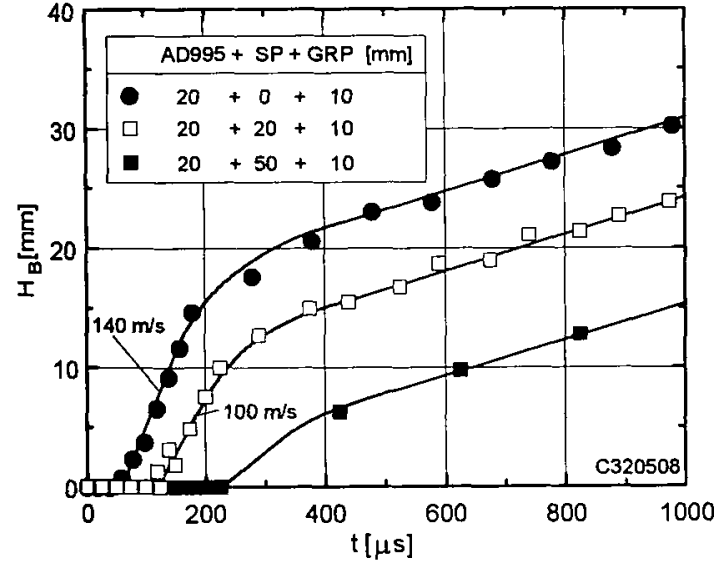

Figure 2: Distance-time histories of GRP bulging $\mathrm{v}_{\mathrm{p}} \approx 700 \mathrm{~m} / \mathrm{s}$

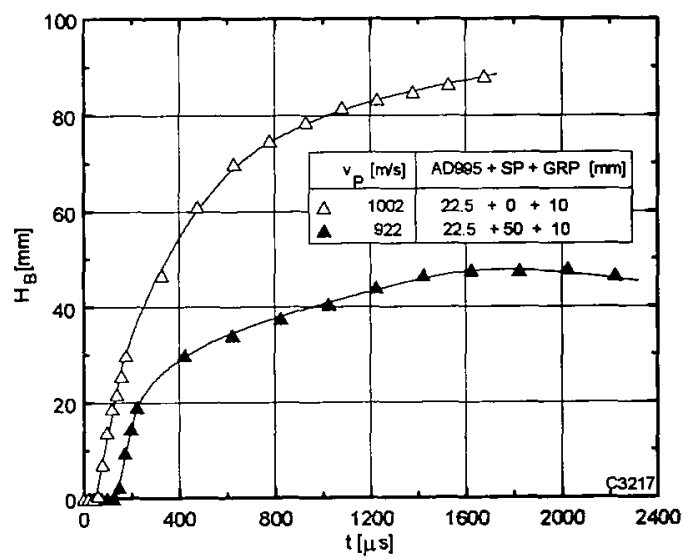

Figure 3: Distance-time histories of GRP bulging $\mathrm{v}_{\mathrm{P}}$ close to ballistic limit velocity 


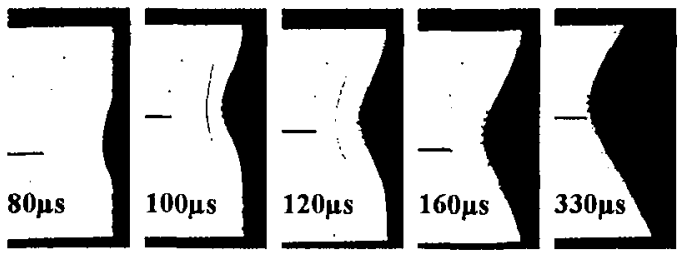

Figure 4a: Shadowgraphs of GRP bulging, AD $995+$ GRP, $v_{P}=1002 \mathrm{~m} / \mathrm{s}$
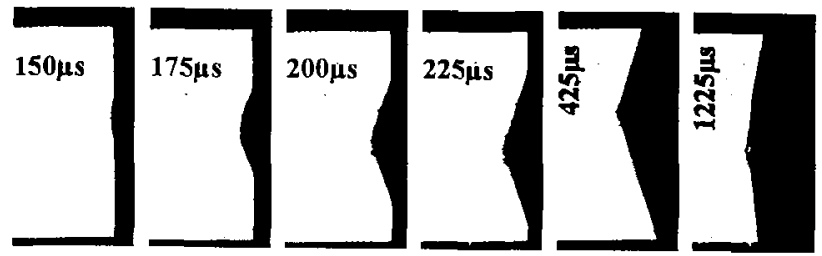

Figure 4b: Shadowgraphs of GRP bulging, AD995 + SP + GRP, $v_{P}=922 \mathrm{~m} / \mathrm{s}$

The influence of the sandwich panels on the ballistic resistance of the composite targets is demonstrated in Figure 5, where the residual projectile velocity is plotted versus impact velocity. The results show that the two-layer configuration Ceramic/GRP exhibits the highest ballistic limit velocity $\mathrm{V}_{\mathrm{BL}}$. The insertion of a sandwich panel reduces $V_{B L}$ by about $100 \mathrm{~m} / \mathrm{s}$ in the case of the $20 \mathrm{~mm}$ panel and about $50 \mathrm{~m} / \mathrm{s}$ in the case of the $50 \mathrm{~mm}$ sandwich panel.

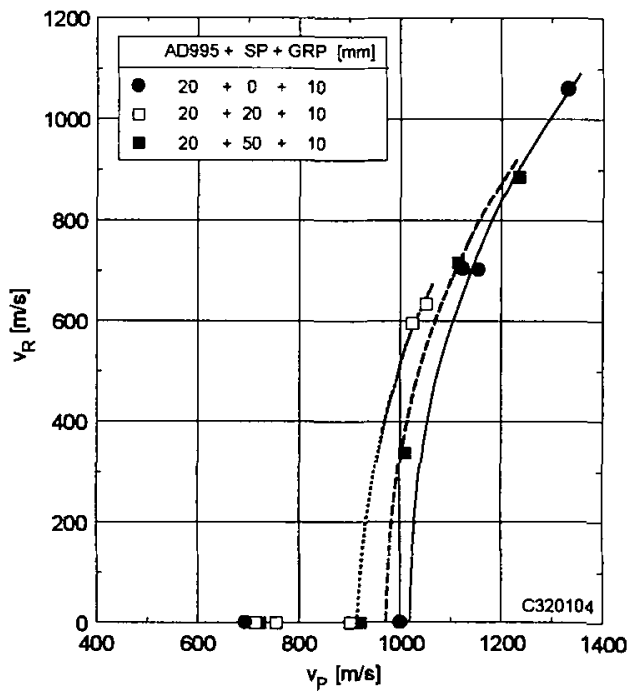

Figure 5: Residual velocity $v_{R}$ versus impact velovity $v_{P}$

A comparative test where the $50 \mathrm{~mm}$ sandwich panel was replaced by a $50 \mathrm{~mm}$ air gap between ceramic and GRP panel yielded the same ballistic resistance with and without sandwich panel. This result suggests that the sandwich panels did not support the ceramic in the way of a backing. The ballistic resistance of the type of composite targets considered here is governed by two major mechanisms, the erosion and the retardation of the projectile by the ceramic and the absorption of the residual kinetic energy of the projectile and ceramic fragments by the glass laminate. The reduction of the ballistic limit by the insertion of a sandwich panel indicates that the efficiency of the ceramic may be reduced in this case. A reduced 
efficiency of the ceramic means a less eroded projectile and/or a less retarded projectile that has to be stopped by the GRP panel. This effect can not be detected at impact velocities significantly below the ballistic limit where the laminate can absorb the residual kinetic energy in any of the three configurations.

An inspection of the targets after the tests showed that the holes in the sandwich panels had diameters in the range from $80 \mathrm{~mm}$ to $100 \mathrm{~mm}$, which can explain the smaller diameter of the bulge observed with the impact velocity close to the ballistic limit (Fig. 4b). However, with the $50 \mathrm{~mm}$ sandwich panel the maximum dynamic bulge height is only half of that of the two-layer configuration.

\subsection{Impact of $12.7 \mathrm{~mm}$ Armour Piercing (steel core) projectiles}

The steel core projectiles were fired at the ordnance velocity of $920 \mathrm{~m} / \mathrm{s}$ and the thickness of the sandwich panels was varied (Table 3). The distance-time histories of the GRP bulging are plotted in Figure 6 . The diagram shows that the sandwich panels had no influence on the bulging velocity with this type of projectile. In contrast to the case of the tungsten projectile, no influence of the sandwich panels on the ballistic resistance was observed. This result can be explained by the fact, that the steel core of the projectile is broken into several fragments during the interaction with the ceramic in any case. Thus, a more or less dense group of projectile fragments hits the GRP panel. In this case the possible effect of different ceramic efficiencies -with and without sandwich panel- probably cannot be detected because the fragmentation of the projectile is a statistical process. This could also explain the parallel course of the distance-time curves. With respect to the distance-time curves it has also to betaken into account, that the areal weight of those targets was significantly above the ballistic limit weight.

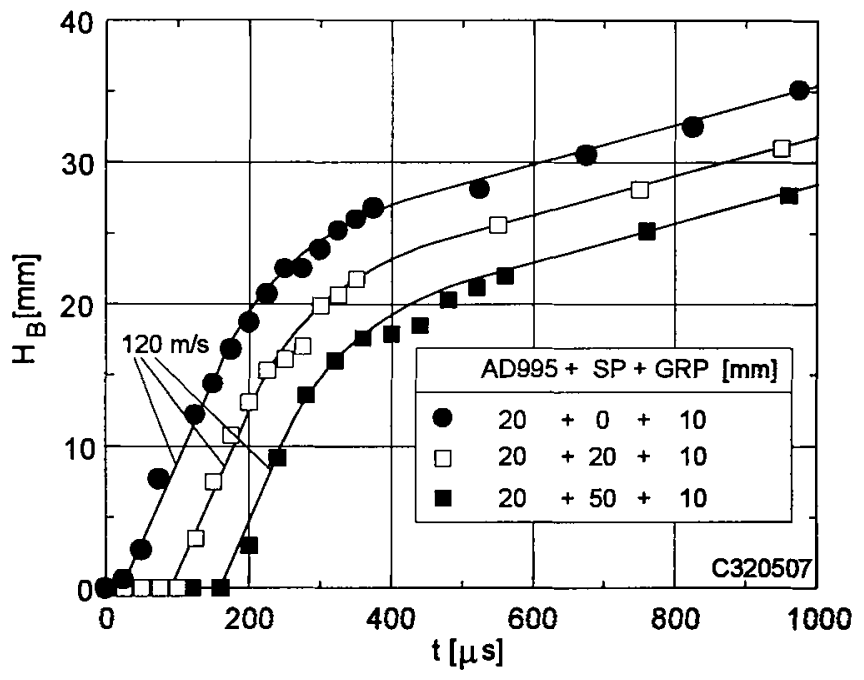

Figure 6: Distance-time histories of GRP bulging at impact of steel core projectiles, $v_{P}=920 \mathrm{~m} / \mathrm{s}$ 


\section{SUMMARY}

The dynamic deformation and the ballistic resistance of two-layer and three-layer composite targets have been determined. At impact of tungsten projectiles the ballistic resistance was reduced when a sandwich panel was inserted between the ceramic tile and the GRP panel. On one hand the sandwich panels caused a reduction of the dynamic and residual static bulge heights, but on the other hand the efficiency of the ceramic appeared to be degraded. In the case of steel core projectiles the sandwich panel had no influence on the ballistic resistance.

\section{Acknowledgements}

The authors are grateful to Mr. Joerg Gonschorek, Mr. Dieter Preuß and Mr Edgar Zipfel who performec the experiments carefully.

\section{References}

[1] Straßburger E., Senf H., Burkins M.S., Gooch W.A., "Dynamic Impact Resistance of Ceramic/GRP Composite Targets", 16th Int. Symposium on Ballistics, San Francisco, CA, USA, 1996

[2] Kokidko D., Gee L., Chou S.C., Chiang F.P., "Method for measuring transient out-of-plane deformation during impact", Int. J. Impact Engng. Vol. 19, No. 2, pp. 127-133, 1997

[3] Bless S.J., Hartman D.R., "Ballistic Penetration of S-2 Glass Laminates", Proceedings 21st International SAMPE Technical Conference, pp. 852-866, September 1989

[4] Vasudev A., Mehlman M.J., "A Comparative Study of the Ballistic Performance of Glass Reinforced Plastic Materials", SAMPE Quarterly, pp. 43-48, July 1987 